\title{
PREPAREDNESS OF STUDENTS FROM PRESCHOOL AND ELEMENTARY PEDAGOGY FOR TEACHING OF TECHNICAL EDUCATION
}

\author{
Mária KOŽUCHOVÁ, Univerzita Komenského v Bratislave, \\ Slovenská republika \\ Martin KURUC*, Univerzita Komenského v Bratislave, \\ Slovenská republika
}

Přijato: 28. 5. 2020 / Akceptováno: 25. 8. 2020

Typ článku: výzkumná studie

DOI: $10.5507 /$ jtie.2020.016

Abstract: In our article, we present the results and interpretations of our research, which aimed to map the current settings of student's academic selfregulation and motivation to learn from pre-primary and primary university education programs. We focused on three areas: on self-regulation and motivation to learn science, mathematical disciplines, and technology education. The research is based on the methodological approach of The Theory of SelfDetermination. The most important finding is the positive setting of students learning motivation to technical education. The Identified regulatory style to technical education prevailed among students from pre-primary and primary education programs.

Key words: self-regulation, motivation, self-determination, technical education.

\section{PRIPRAVENOSŤ ŠTUDENTOV PREDŠKOLSKEJ A ELEMENTÁRNEJ PEDAGOGIKY NA VÝUČBU PRACOVNÉHO VYUČOVANIA}

Abstrakt: V príspevku predstavujeme výsledky a interpretácie z nášho výskumu, ktorého cielom bolo vytvorit' si určitý obraz o tom, ako je nastavená sebaregulácia a motivácia k učeniu sa študentov programov Predškolská a elementárna pedagogika a Učitel'stvo primárneho vzdelávania pre predmety technického charakteru. Sústredili sme sa na oblast' pripravenosti, sebaregulácie a motivácie k technickému vzdelávaniu. Vychádzame z metodologického prístupu ukotveného $v$ teórii sebaurčenia. Za najvýznamnejšie zistenie považujeme pozitívne nastavenie motivácie študentov $k$ technickým predmetom.

Klíčová slova: sebaregulácia, motivácia, sebaurčenie, technické vzdelávanie.

\footnotetext{
*Autor pro korespondenci: kuruc@fedu.uniba.sk
} 


\section{1 Úvod}

Predmetu pracovné vyučovanie sa na základných školách venuje malá pozornost', ako zo strany štátu (nízka časová dotácia v rámci Rámcového učebného plánu - 1 h. týždenne v 3. ročníku a 1 h. vo 4. ročníku ZŠ), tak aj zo strany učitel'ov (často učitelia tieto hodiny využívajú na doučovanie tzv. hlavných predmetov. Vzhl'adom na súčasnú situáciu (COVID 19) už ministerstvo SR avizuje, že v budúcom školskom roku vzdelávacia oblast' Človek a svet práce nebudú prioritou vzdelávania. Podl'a nášho názoru je technika významnou súčast'ou l'udskej kultúry, vždy bola úzko spätá s tvorivou pracovnou činnost'ou človeka. Človek bol, je a bude hlavným iniciátorom akýchkol'vek technologických inovácií a zmien, ktoré stále intenzívnejšie vstupujú do jeho profesionálneho i súkromného života. (Martin, 2018)

Technika ovplyvňuje naše postoje, hodnoty, psychické a fyzické zdravie, konanie a životný štýl. Štáty EU venujú vel'kú pozornost' technickému vzdelávaniu. Pri tvorbe aktuálnych vzdelávacích programov vychádzajú z odporúčania Rady Európy (2006), ktorá určila hlavný strategický ciel': vytvorit' také vzdelávacie programy, aby sa Európska únia vyznačovala dynamickou a bola konkurencie schopnou ekonomikou sveta. Viacerí autori v posledných rokoch upozorňujú, že je potrebné zvýšit' záujem žiakov o štúdium prírodovedných a technických odborov, rozvíjat' ich vedecko-technické kompetencie, zaistit' všetkým žiakom prístup k informačným a komunikačným technológiám, zlepšit' prípravu učitel'ov pre prírodovedné a technické vzdelávanie a upevnit' väzbu medzi svetom práce a výskumom (Kozík a kol., 2013 Dostál,2015; Dostál a Prachagool, 2016). Aj nás to viedlo k pozornejšiemu sústredeniu našich výskumných aktivít na hlbšiu analýzu prípravy študentov na výučbu pracovného vyučovania. Zaujímala nás aj vedomostná, ale hlavne motivačná stránka prípravy. Našim ciel'om bolo hl'adat' stratégie vzdelávania, ktoré odstránia zablokovanie pracovnej pamäte študentov. Tieto vzdelávacie stratégie sme sa snažili hl'adat' vo výskumnom kontexte (Částková, Kropáč a Plischke, 2016; Č́stková, 2018). Matematická a vedecko-technická gramotnost' absolventov je citlivo vnímaná aj trhom práce. Bez matematiky, prírodných vied a techniky nedosiahneme výrazný pokrok v ekonomike.

\section{Ciele technického vzdelávania $v$ materskej škole a na primárnom stupni ZŠ}

Technické vzdelávanie v materskej škole je zaradené do vzdelávacej oblasti Človek a svet práce. Vytvorených je pät' vzdelávacích oblastí identických s predmetom pracovné vyučovanie na primárnom stupni (materiály a ich vlastnosti, konštruovanie, užívatel'ské zručnosti, technológie výroby, remeslá a profesie). Pozornost' detí sa zameriava na skúmanie vlastností rôznych materiálov, zvažovaní možnosti ich využitia pri tvorbe špecifických výrobkov. Deti navrhujú jednoduché riešenia konštrukcií známych objektov (domy, mosty). Učitel'/ka vytvára situácie, v ktorých majú deti možnost' spontánne vyberat' náradie na prípravu a/alebo úpravu predmetov. Taktiež diskutujú o známych remeslách, pričom sa sústred'uje pozornost' na ich aktuálnu skúsenost'. Technické vzdelávanie počnúc materskou školou predstavuje pre diet'a prvú ponuku profesijnej vol'by.

Pracovné vyučovanie na primárnom stupni vzdelávania je zamerané na široké spektrum pracovných činností a technologických postupov založených na tvorivej a tímovej spolupráci. Technickým vzdelávaním sú žiaci vedení $\mathrm{k}$ získaniu základných užívatel'ských zručností v rôznych oblastiach l'udskej činnosti. Predmet pracovné vyučovanie doplňuje celé základné vzdelávanie o dôležitú zložku nevyhnutnú pre 
uplatnenie človeka v d’alšom živote a v spoločnosti. Predmet je orientovaný na vnímanie praktickej stránky okolitého sveta. Umožňuje žiakom a ich rodičom správne a včas rozpoznat ich profesijnú preferenciu. Dosiahnut' harmonický a celistvý rozvoj osobnosti mladého človeka tak, aby jeho schopnosti a nadanie mohli byt' najlepšie uplatnitel'né $\mathrm{v}$ reálnom živote.

V neposlednom rade predstavuje dôležitý prirodzený činitel' v prirodzenom rozvoji hrubej a jemnej motoriky detí, či zvyšuje ich kognitívno-motorickú pripravenost' na školu. (Montessori, 2017; Reeve a Lee, 2012) Tento predmet je aj významným prirodzeným motivačným činitel’om v procese prípravy detí na školu. (Deci, 1995)

Ak má vzdelávanie pripravit' žiakov na ich lepšie budúce uplatnenie sa vo vedeckotechnickej oblasti, tak sa v ňom nemôžeme uspokojit' len s remeselníckym prístupom. Prekonané sú aj behavioristické prístupy založené na prispôsobovaní, jednostrannej akceptácii kategórie výkonu. Dôraz sa kladie na sprostredkovanie bohatej sociálnej skúsenosti $\mathrm{s}$ technikou a poznávanie $\mathrm{v}$ autentickom sociálnom a kultúrnom kontexte, vrátane formovania postojov $\mathrm{k}$ technickému vzdelávaniu. Žiaci sú stále viac vedení ku kritickému hodnoteniu, kladeniu vlastných otázok, diskutovaniu a zdiel’aniu svojich vlastných postojov a názorov.

\section{Zastúpenie predmetov technického charakteru v študijných programoch}

$\mathrm{Z}$ vyššie uvedených ciel’ov technického vzdelávania $\mathrm{v}$ predprimárnom a primárnom stupni prirodzene vyplýva, že na jeho výučbu by učitel' mal byt' dobre pripravený po odbornej, praktickej aj metodickej stránke. Urobili sme analýzu a komparáciu študijných programov PEP (bakalársky študijný program: Učitel'stvo pre materské školy a vychovávatel'stvo pre školské kluby) a UPV (magisterský študijný program: Učitel'stvo pre primárne vzdelávanie) na troch pedagogických fakultách na Slovensku - v Bratislave, Banskej Bystrici a Ružomberku.

Môžeme konštatovat', že predmety zamerané na technické vzdelávanie na jednotlivých fakultách majú výrazne rozdielne zastúpenie. Najvýraznejšie zastúpenie majú v študijných programoch na Pedagogickej fakulte KU v Ružomberku. Na bakalárskom stupni je to povinný predmet Technická predškolská a mimoškolská edukácia (1/2) a povinne volitel’ný predmet Technická a výtvarná záujmová činnost', ktorú si študent vyberá zo skupiny viacerých predmetov. $\mathrm{V}$ rámci magisterského štúdia je zaradený povinný predmet Primárne technické vzdelávanie (1/1) a povinne volitel'ný predmet Ludové tradície a remeslá (študent si ho môže vybrat' zo skupiny 4 predmetov).

Technické vzdelávacie predmety na Pedagogickej fakulte UMB v Banskej Bystrici sa vyznačujú tým, že sú zväčša integrované s prírodovedným vzdelávaním. Považujeme to za dobrý prístup, pretože tieto predmety majú vel’a spoločných znakov. V rámci bakalárskeho stupňa je to povinný predmet Prírodovedné a technické vzdelávanie (1-2-2) a povinne volitel'ný predmet Práca s technickým materiálom v MŠ a ZŠ (0-2-0). V rámci magisterského štúdia UPV je to povinný predmet Didaktika prírodovedných a technických predmetov s praxou (0-2-1-1) a výberový predmet Výberový seminár $\mathrm{k}$ didaktike prírodovedných a technických predmetov (0-2-0-0).

Ak hodnotíme predmety technického charakteru $\mathrm{v}$ rámci PEP a UPV, tak najkritickejšia situácia je na Pedagogickej fakulte UK v Bratislave. Predmety technického charakteru nemajú v rámci povinných predmetov žiadne zastúpenie, ako na bakalárskom, tak aj na magisterskom stupni štúdia. Znamená to, že značná čast’ študentov 
odchádza do praxe bez náležitej prípravy. Čiastočne sú pripravení tí študenti, ktorí absolvujú povinne volitel'ný predmet, a to na bakalárskom stupni Rozvíjanie technickej gramotnosti (2S) a na magisterskom stupni výberový predmet Technická výchova v primárnom vzdelávaní (2PS).

Čo sa od absolventov primárnej pedagogiky očakáva $v$ rámci ich univerzitnej prípravy a následnej pedagogickej praxe? Je vel'mi t’ažké presne určit', aký je ideálny model pregraduálnej prípravy budúcich učitel’ov $\mathrm{v}$ oblasti technického vzdelávania. Rozhodne je potrebné zdôraznit', že na obidvoch stupňoch vzdelávania by mal mat' medzi povinnými predmetmi svoje zastúpenie minimálne jeden predmet technického charakteru. Vo svojej podstate by nemalo íst' o mechanické spojenie obsahu a didaktiky vyučovania, ale o tzv. didaktickú znalost' obsahu. Pri preberaní určitého obsahu študent si má uvedomit' didaktickú transformáciu preberaného učiva: uvedomit' si vekové odlišnosti detí, ich schopnost' porozumiet' obsahu učiva, vnímat' prekoncepty detí a pod.

V oblasti techniky neustále dochádza ku korekcii poznania. Jedna teória strieda druhú, mení sa aj pohl’ad na techniku a jej využívanie. Ťažisko je v prekonávaní rozporu medzi predchádzajúcim a súčasným poznaním. Dôraz sa kladie na rozvoj vyšších poznávacích funkcií (rozvoj kritického a tvorivého myslenia). Žiak je postavený do úlohy bádatel'a (výskumníka) a hl'adá odpoved' na otázku (problémovú úlohu). Príprava budúcich učitel’ov v oblasti technického vzdelávania je chápaný ako kolaboratívny proces zdiel’ania a porovnávania názorov a hl’adísk prostredníctvom konverzácie, diskusie a vzájomnej kritiky.

\section{Ciele a metódy výskumu, výskumný nástroj}

Ciel’om výskumu bolo vytvorit' si určitý obraz o tom, ako je nastavená pregraduálna príprava, ale hlavne motivácia študentov programov Predškolská elementárna pedagogika a Učitel'stvo primárneho vzdelávania. Sústredili sme sa na tri oblasti predmetov: matematické, prírodovedné a technické. Výskum sme realizovali na troch pedagogických fakultách, a to v Bratislave, Banskej Bystrici a v Ružomberku. Využili sme pritom teóriu sebaurčenia autorov Richarda M. Ryana a Edwarda L. Deciho (Ryan a Deci, 2004), čím sme získali významné informácie o vnútorných a vonkajších faktoroch sebaregulácie (predvídanie, plánovanie, monitorovanie a sebahodnotenie) študentov - budúcich učitel’ov. Ako výskumný nástroj sme použili dotazník SRQ-Academic (Ryan a Connel, 1989), ktorý bol štandardizovaný v roku 2017 na Slovenské prostredie (Kuruc, 2017). Pre naše potreby sme dotazník modifikovali tak, aby zaznamenával charakter motivácie vo vzt’ahu $\mathrm{k}$ technickému, matematickému a prírodovednému vzdelávaniu.

Dotazník vyhodnocuje individuálne odlišnosti v typoch motivácie a regulácie učenia sa pre zadanú oblast' - pole pôsobnosti. V našom prípade ide o motiváciu a reguláciu učenia sa prírodovedných, matematických a technických predmetov počas pregraduálnej prípravy študentov. Ide o tieto štyri motivačno-regulačné štýly učenia sa: Externá regulácia - študent sa učí preto lebo sa snaží vyhnút' trestu alebo získat' odmenu. Introjikovaná regulácia - študent sa učí, pretože sa snaží vyhnút' nepríjemným pocitom viny a hanby alebo dosiahnut' stav podmienenej sebaúcty (vnímanie vlastnej hodnoty na základe pochvaly zo strany autority). Identifikovaná regulácia - predstavuje motiváciu na základe sily vnímanej osobnej hodnoty predmetu pre študenta. Intrinsická (vnútorná) motivácia - pri ktorej je študent tak hlboko ponorený do daného predmetu, že mu to prináša radost' a potešenie. (Deci a Ryan, 2004; Ryan, 2012; Kuruc, 2017). 
Prvé dva regulačné štýly (externá a introjikovaná regulácia) sú formované prístupom založeným na kontrole - kontrolná motivácia, pri ktorej zohrávajú rozhodujúci vplyv očakávania zo strany učitel'a. Samotný záujem žiaka o predmet je vnímaný ako sekundárny. Predstavujú učenie sa založené na externom tlaku a kontrole prostredia. Ďalšie dva regulačné štýly (identifikovaná regulácia a intrinsická motivácia) sú formované $\mathrm{v}$ prostredí nastavenom na podporu autonómie študenta - autonómna motivácia (Deci a Ryan, 2004; Ryan, 2012; Kuruc, 2017). Predstavujú teda učenie sa študenta vychádzajúce $\mathrm{z}$ jeho vnútorných motívov ako je vnímaná hodnota daného predmetu alebo hlboký záujem a zanietenie o predmet.

Reliabilitu modifikovaného dotazníka SRQ-Academic sme overovali troma spôsobmi. Prvým bola Split-half reliabilita, ktorá dosiahla akceptovatel'nú hodnotu 0,687. Ked’že ide o dotazník, ktorého konštrukcia je založená na klasických Likertových škálach ako druhú metódu sme zvolili Cronbachovú alfu, ktorej výsledná hodnota dosiahla uspokojivú hodnotu 0,845 . Táto metóda sa využíva na posúdenie vnútornej konzistencie škálovaných položiek. Ako tretiu metódu sme využili posúdenie Scott's homogenity, ktorá dosiahla taktiež akceptovatel'nú hodnotu 0,647. Pre overenie konštrukčnej validity dotazníka sme využili klasickú faktorovú analýzu položiek. Táto nepreukázala žiadne výraznejšie odlišnosti od pôvodného dotazníku (Kuruc, 2017) v príslušnosti jednotlivých položiek k meraným štýlom regulácie a motivácie. Na základe týchto výsledkov sme mohli konštatovat', že nami zvolený výskumný nástroj spol'ahlivo a presne umožňuje vyhodnotit' aký sebaregulačný štýl u respondentov prevláda.

\section{Výskumný súbor}

Výberový súbor bol zostavený na základe zámerného výberu. Našou ciel'ovou skupinou boli študenti programov Predškolská a elementárna pedagogika a Učitel'stvo pre primárne vzdelávanie. Ako kritérium výberu bolo zastúpenie všetkých troch pedagogických fakúlt, a to tak na bakalárskom, ako aj magisterskom stupni. Respondenti na jednotlivých fakultách boli oslovovaní náhodne. Do výskumu bolo zapojených 1149 študentov, z toho 467 študentov z Ružomberku, 444 z Bratislavy a 238 z Banskej Bystrici. Zastúpenie mužského pohlavia bolo zanedbatel'ná - vzorku tvorili dominantne respondenti ženského pohlavia. V prípade fakulty v Ružomberku bola návratnost' dotazníkov na úrovni $98 \%$ a v Bratislave $77 \%$. Najnižšie zastúpená (56 \%) bola návratnost’ z fakulty v Banskej Bystrici.

\section{Interpretácie výsledkov výskumu}

Rozloženie zozbieraných dát sme overili prostredníctvom testov normality Kolmogorov-Smirnov a Shapiro-Wilk. Na základe výsledkov v tabul'ke 1. vidiet', že dáta nepochádzajú z normálnej distribúcie. Preto sme pri d’alšej analýze rozdielov a vzt’ahov využili neparametrické testy.

Deskriptívna štatistika výberového súboru z konečného skóre tzv. RAI-Relatívneho autonómneho indexu, pre posúdenie sebaregulačného štýlu učenia sa technicky orientovaných predmetov na jednotlivých pedagogických fakultách nám potvrdila výsledky testov normality (viac tabul'ka 1.) 


\begin{tabular}{|l|c|c|c|c|c|c|c|}
\hline & $\begin{array}{c}\text { Valid } \\
\text { cases }\end{array}$ & Mean & Std. Er. & Var. & $\begin{array}{c}\text { Std. } \\
\text { Dev. }\end{array}$ & Skew & Kurtosis \\
\hline Technika RK & 221 & 0,631 & 0,144 & 4,574 & 2,139 & $-0,052$ & 0,410 \\
\hline Technika BA & 167 & 0,249 & 0,168 & 4,686 & 2,165 & 0,522 & 0,716 \\
Technika BB & 100 & 0,665 & 0,244 & 5,950 & 2,439 & 0,167 & 0,191 \\
\hline
\end{tabular}

Tab. č. 1: Deskriptívna štatistika výberového súboru.

Ako sme už spomenuli určujúcou hodnotou záverečného skóre bola hodnota tzv. RAI - Relatívneho autonómneho indexu tak, ako ju vymedzili Ryan a Connel (1989). Tento index predstavuje mieru autonómnej motivácie/regulácie, tzn. nakol’ko človek reguluje svoje učenie sa, alebo je k nemu motivovaný z vnútra.

Naša prvá výskumná otázka znela: Aké štýly sebaregulácie učenia prevládajú u študentov vjednotlivých predmetoch (so zameranim na matematiku, prírodovedu a techniku)?

V porovnaní s matematickými a prírodovednými predmetmi sa u študentov prejavil najväčší záujem o technicky orientované predmety (obr.1). Kým v matematike prevažoval tzv. ER - externý (motivácia k učeniu na základe odmeny a trestu) a IJR - introjikovaný (motivácia $\mathrm{k}$ učeniu sa je na základe snahy vyhnút' sa pocitom viny a hanby alebo podmienenej sebaúcty) štýl regulácie. V prípade technického vzdelávania, signifikantne výraznejšie prevažoval tzv. IDR - identifikovaný štýl regulácie (respondent vidí osobný zmysel v získaných vedomostiach a zručnostiach) a IM - vnútornej motivácie (činnost' je spojená s preživaním radosti z vykonávanej činnosti).

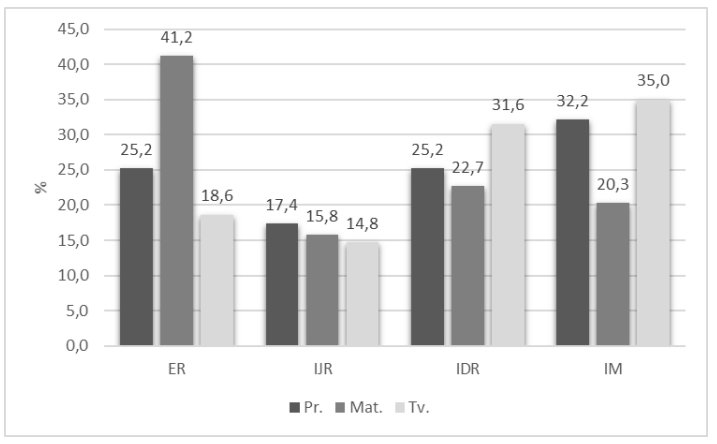

Obr. č. 1: Frekvencia výskytu sebaregulačného štýlu podla predmetov.

Pri predmetoch zameraných na techniku signifikantne výrazne prevažovali autonómne regulačné štýly (identifikovaný a vnútorná motivácia). Kým v prírodovednej oblasti 
prevažovala regulácia založená na potešení a radosti z predmetu. Pri matematicky orientovaných predmetoch bol dominantne zastúpený externý štýl regulácie (obr. 1).

Druhá výskumná otázka znela: Aké sú rozdiely vo vnútornej motivácii medzi študentmi $v$ bakalárskom stupni a študentmi v magisterskom stupni štúdia?

Na obrázku č. 2 môžeme vidiet', že najvýraznejšie stúpla hodnota priemerného skóre RAI v 3. ročníku bakalárskeho stupňa. Pozoruhodný je výraznejší pokles priemerného skóre RAI v poslednom ročníku magisterského štúdia. Napriek tomu, že tieto rozdiely sa môžu na prvý pohl'ad zdat' výrazné v skutočnosti priemerné hodnoty RAI oscilujú $\mathrm{v}$ intervale od $-0,3$ do 0,3 . Čo nie je príliš široký interval a v konečnom dôsledku tieto zmeny nemusia byt' signifikantné.

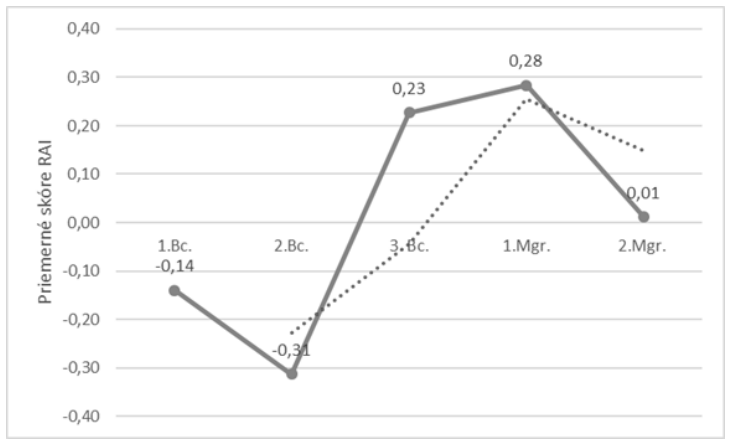

Obr. č. 2: Trendová krivka priemernej hodnoty RAI-Technické predmety

Testovanie rozdielov medzi jednotlivými ročníkmi ukázalo, že nie sú medzi nimi signifikantné rozdiely. Táto skutočnost' môže byt' spôsobená pomerne vyrovnaným výskytom tzv. autonómnych typov regulácie učenia sa, tj. IDR - identifikovaného štýlu regulácie a hlavne IM - vnútornej (intrinsickej) motivácie (obrázok č. 3) v jednotlivých rokoch štúdia (obrázok č. 3), ktoré sú označované ako autonómne typy motivácie. Taktiež pomerne vyrovnaným výskytom ER - externej a IJR - introjikovanej regulácie, ktoré sú tiež označované ako kontrolné štýly motivácie (Ryan a Deci, 2004; Kuruc, 2017). 


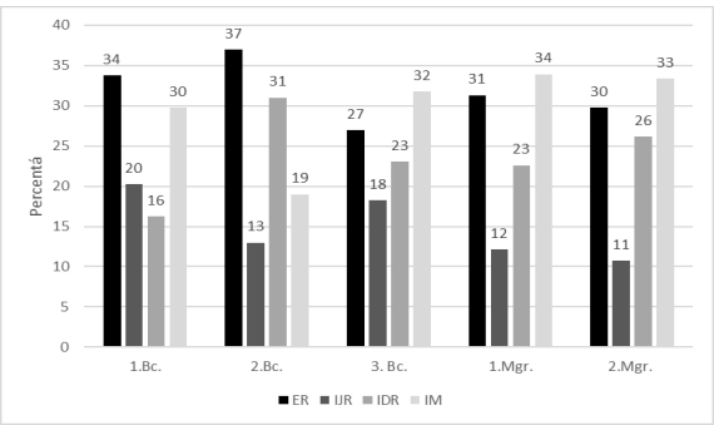

Obr. č. 3: Frekvencia výskytu regulačných štýlov učenia sa podl’a stupňa štúdiaTechnické predmety

Tretia výskumná otázka znela: Aké sú rozdiely medzi študentmi v dennej a externej forme štúdia? Medzi jednotlivými formami štúdia sme nezaznamenali štatisticky významné rozdiely. Pozoruhodné je, že v externej forme štúdia bol nižší výskyt externého regulačného štýlu a vyšší výskyt identifikovaného regulačného štýlu. Predpokladáme, že tento rozdiel môže byt' spôsobený tým, že externí študenti sú vyššej vekovej kategórie než denní študenti, teda je tu vplyv určitej životnej skúsenosti. Taktiež je možné, že určitú úlohu môže zohrávat' ich pravdepodobne dobrovol'nejšie rozhodnutie pre štúdium (bez sociálneho tlaku, ktorý u denných študentov vnímame ako výraznejší vzhl'adom na spoločenské očakávanie po skončení strednej školy pokračovat' vo vysokoškolskom štúdiu). Taktiež je na zváženie úvaha spojená s financovaním vlastného štúdia u študentov externej formy štúdia, teda aj vnímanie väčšej zodpovednost' za vlastné štúdium.

Pri štvrtej výskumnej otázke sme zist'ovali: aké sú rozdiely medzi jednotlivými fakultami. V prípade predmetov zameraných na technické vzdelávanie, sa ukázali najpestrejšie rozdiely vo výskyte jednotlivých regulačných štýlov medzi fakultami. V prípade fakulty $\mathrm{v}$ Ružomberku je signifikantne najčastejšie zastúpená vnútorná motivácia (29 \%), zároveň hned’ za ňou je externá regulácia (24 \%). Vel’mi podobne je to aj v prípade výberového súboru $\mathrm{z}$ fakulty v Banskej Bystrici, kde bola vnútorná motivácia (34 \%) zastúpená najčastejšie a hned’ za ňou bola externá regulácia (31\%). V prípade Pedagogickej fakulty v Bratislave sa ukázalo iné rozloženie regulačných štýlov medzi študentmi. Signifikantne častejšie bol zastúpený v tejto vzdelávacej oblasti externý štýl regulácie (35\%), po ňom nasleduje síce výrazne autonómnejší, ale stále zo spektra externej motivácia - identifikovaný štýl regulácie $(29 \%)$. Tretia v poradí je vnútorná motivácia (25 $\%)$.

Napriek týmto špecifikám, ktoré prináša analýza frekvencie výskytu regulačných štýlov, d’alšie testovanie medzi priemernými hodnotami RAI fakúlt nám ukázalo, že v oblasti technických predmetov, medzi nimi nie sú signifikantné rozdiely. 


\section{Záver}

Pre lepšie štruktúrovanie sme sa pri rámcovaní interpretácií výsledkom výskumu opreli o metódu SWOT analýzy. Využili sme ju skôr ako nástroj pre sumarizovanie podnetov, postrehov a d'alších úvah súvisiacich s výsledkami nášho výskumu. Nižšie prezentované výstupy sa týkajú len technicky orientovaných predmetov.

SILNÉ STRÁNKY - vlastnosti, ktoré môžu napomôct' $\mathrm{k}$ dosiahnutiu ciel'a:

- Výrazne prevládajú vnútorné zdroje sebaregulatívneho učenia. Študenti vnímajú u seba vyššiu mieru autonómie, kompetencie a zaangažovania.

- U študentov prevláda autonómny štýl motivácie k učeniu.

- $\quad$ Z pohl'adu formy štúdia sa neukázali žiadne rozdiely v motivačnom/regulačnom štýle. V oboch skupinách je výraznejší výskyt autonómnych štýlov učenia sa.

SLABÉ STRÁNKY - vlastnosti, ktoré st’ažujú dosiahnutie ciel'a:

- $\quad$ Technické disciplíny absolvuje počas štúdia približne 50\% študentov.

- Výrazné zastúpenie výskytu externej regulácie učenia sa na začiatku štúdia a s tým spojené negatívnejšie (opatrnejšie) postoje k technickým disciplínam.

- $\quad$ Napriek klesajúcemu trendu výskytu kontrolných štýlov u študentov v bakalárskom štúdiu a stúpajúcom trende výskytu identifikovanej regulácie (to čo sa učím, má pre mňa vel'ký význam; je pre mňa hodnota) zostáva vo všetkých ročníkoch frekvencia výskytu externej regulácie nad $30 \%$ z celkového súboru respondentov.

PRÍLEŽITOSTI - externé podmienky, ktoré môžu dopomôct' k dosiahnutiu ciel'a:

- V technickom vzdelávaní je možno zabezpečit' podporu autonómnych štýlov nielen cez systémové opatrenia ako sú zmeny v akreditácii (volitel'né/nevolitel'né predmety a ich zaradenie do jednotlivých semestrov štúdia) ale aj cez vytváranie priestoru pre realizáciu zaujímavých študentských projektov založených na princípoch kooperatívneho učenia a sociálneho konštruktivizmu.

- Možnost' zapájania do tvorby zaujímavých projektov, ktoré študenti považujú za zmysluplné pre prax.

- Vidíme príležitost' aj pre využívanie princípov kooperatívneho vzdelávania a sociálneho konštruktivizmu, ktoré podporujú študentmi vnímanú vlastnú autonómiu.

- $\quad$ K príležitostiam zarad'ujeme aj viac možností využívania učitel'ovej kreativity, na seminároch $\mathrm{v}$ rámci technických disciplín.

OHROZENIA - externé podmienky, ktoré môžu st'ažit' dosiahnutie ciel'a:

- Ak si uvedomíme, že vzdelávacia oblast' Človek a svet práce je zaradená už do vzdelávacieho programu materskej školy a následne aj na prvom stupni základnej školy, tak nie je nám jasné, ako budú pripravení do praxe ostatní študenti, ktorí nemali možnost' pripravit' sa pre túto vzdelávaciu oblast' počas štúdia, pretože na niektorých fakultách technické disciplíny do študijného programu boli zaradené len ako výberové. Podl'a nášho názoru by mali byt' študenti pripravení na výučbu vo všetkých vzdelávacích oblastiach a pre stupeň, na ktorý sú pripravovaní.

- V V prvých dvoch rokoch štúdia na bakalárskom stupni prevláda externý regulačný štýl. 
- $\quad$ Aktuálne je pomerne nízke materiálno-technické vybavenie dostupné pre učitel’ov seminárov technických predmetov a taktiež nevyhovujúce priestorové nastavenie.

Zaujímavým zistením je, že u študentov PEP a UPV sa prejavil vyšší výskyt autonómiu podporujúci štýl učenia sa $\mathrm{v}$ predmetoch technického charakteru (v porovnaní s matematickými a prírodovednými predmetmi). Za výrazný úspech považujeme zistenie, že $\mathrm{v}$ technickom vzdelávaní $\mathrm{v}$ priebehu štúdia autonómnost' študentov ma tendenciu narastat'. Otázkou zostáva, či je to zásluha učitel'ov technických disciplín, ktorí u študentov podporujú autonómny štýl učenia sa, a to na všetkých sledovaných fakultách, alebo fakt, že tieto predmety patria skôr do kategórie dobrovol'ne volitel'ných. Možné je, že do tohto javu vstupuje aj mnoho d'alších premenných, ktoré by si zaslúžili podrobné preskúmanie. Objektívne získané závery nám umožnili lepšie poznat' charakter pripravenosti, motivácie a sebaregulácie učenia sa študentov v oblasti technického vzdelávania. Za významný prínos riešenia problematiky považujeme realizáciu výskumných aktivít priamo $\mathrm{v}$ pedagogickom procese, $v$ rámci ktorého študenti mali možnost' vnímat' objektívne zistený charakter motivácie, ale aj samotného procesu učenia sa. Odhalit' nedostatky a diskutovat' o zistených záveroch spolu s pedagógmi. Spracované výsledky výskumu vyúst’ujú jednak do obohatenia súčasnej teórie o rozvoji sebaregulácie učenia sa a identifikácia mechanizmov fungovania sebaregulácie učenia sa študentom pomohla lepšie zvládat' problematiku predmetov, ktoré budú na základnej škole vyučovat'.

V každom prípade na základe našich výsledkov je vidiet', že tak ako prírodovedne orientované, tak aj technicky orientované predmety majú v sebe potenciál roziskrit' u študentov ich zvedavost', zapálit' ich vášeň pre predmet a rozpútat' ich genialitu (Martin, 2018).

Spracované ako výstup v rámci projektu VEGA 10443/18 Analýza sebaregulačných štýlov učenia sa študentov odboru predškolská a elementárna pedagogika.

\section{Literatúra}

Částková, P., Kropáč, J., Plischke J. (2016). Přínos informálního a neformálního vzdělávání pro technické vzdělávání žáků základní školy. Journal of Technology and Information Education. Roč. 8. Č́́slo 2. pp. 53 - 66. DOI 10.5507/jtie.2016.010.

Částková, P. (2018). Rozvoj sebehodnocení žáka v technické výchově na primární škole. Olomouc: UP v Olomouci.

Deci, E. L. (1995) Why We Do What We Do: Understanding Self-Motivation. London: Penguin Books.

Deci, E. L. \& Ryan, R. M. (2004) Overview of Self-Determination Theory: An Organismic Dialectical Perspective. In E. L. Deci \& R. M. Ryan (Eds.), Handbook of SelfDetermination Reseach (pp 3-33). New York: The University of Rochester Press.

Dostál, J. (2015). Badatelsky orientovaná výuka: pojetí, podstata, význam a prínosy. Olomouc: Univerzita Palackého v Olomouci.

Dostál, J., Prachagool, V. (2016). Technické vzdělávání na křižovatce - historie, současnost a perspektivy. Journal of Technology and Information Education. Roč. 8. Číslo 2. pp. 5 - 24. DOI: 10.5507/jtie.2016.006.

Kozík. T. \& kol. (2013). Analýza a zdôvodnenie revízie vzdelávacej oblasti Človek a svet práce. Učitel'ské noviny. - ISSN 0139-5769, Roč. 60, č. 11 (2013), s. 25-27. 
Kuruc, M. (2017). Príručka pre používanie dotazníka SRQ-Academic v pedagogickej praxi. Bratislava, Univerzita Komenského.

Rada Európy. (2006). Odporúčanie EP a RADY z 18. decembra 2006 o klúčových kompetenciách pre celoživotné vzdelávanie. Dostupné na: https://eur-lex.europa.eu/legalcontent/SK/TXT/PDF/?uri=CELEX:32006H0962\&from=EN

Martin K. (2018). Learner Centered Innovation. London: IM Press.

Montessori, M. (2017). Objevování dítěte. Praha: Portál.

Ryan, R. M. (2012). Motivation and the Organization of Human Behavior: Tree Reasons for the Reemergence of Field. In R. M. Ryan (Ed.) The Oxford Handbook of Human Motivation (pp. 3-10). New York: The Oxford University Press.

Ryan, R. M., \& Connell, J. P. (1989). Perceived locus of causality and internalization: Examining reasons for acting in two domains. Journal of Personality and Social Psychology, 57, 5, 749-761.

Ryan, R. M., \& Deci, E. L. (2004). Self-determination Theory and the facilitation of intrinsic motivation, social development, and well-being. American Psychologist, 55, pp. $68-78$. 